\title{
PERBEDAAN TINGKAT NYERIDAN TEKANANDARAH SEBELUM DAN SESUDAH DEEP BREATHING EXERCISE (DBE) PADA PASIEN POST LAPARATOMI
}

\author{
Pradnja Paramitha Chandra Devi, Rudi Hamarno, Roni Yuliwar \\ Poltekkes Kemenkes Malang, Jl. Besar Ijen No 77 C Malang \\ Email : rhamarno@yahoo.com
}

\section{The Differences of Pain Level and Blood Pressure Before and After DBE in Patients Which is Lead Laparotomy Surgery}

\begin{abstract}
This study aims to determine the differences of pain level and blood pressure before and after $D B E$ in patients which is lead laparotomy surgery at Lavalette Hospital Malang. The research method used one group pre-post test design. The subjects of the study were post laparatomy patients selected by purposive sampling technique as many as 20 respondents. The result of paired t-test statistic shows there are significant differences before and after deep breathing exercise (DBE) of pain level with $p$ value $=0.000(p<0,05)$. However, there are not significant differences of sistole blood pressure with $p$ value $=0.725$, and diastole blood pressure with $p$-value $=0.428$ ( $p>0,05)$. Suggestions for nurses to perform DBE actions in patients post laparotomy surgery because effective for decrease pain level.
\end{abstract}

Keywords: post laparatomy, pain level, blood pressure, deep breathing exercise

\begin{abstract}
Abstrak: Penelitian ini bertujuan untuk mengetahui perbedaan tingkat nyeri dan tekanan darah sebelum dan sesudah dilakukan DBE pada pasien yang mengalami pembedahan laparatomi di RS Lavalette Malang. Metode penelitian yang digunakan adalah one group pre-post test design. Subyek penelitian adalah pasien post laparatomi yang dipilih dengan teknik purposive sampling sebanyak 20 responden. Hasil uji statistik paired t-test menunjukkan bahwa terdapat perbedaan signifikan sebelum dan sesudah deep breathing exercise (DBE) dari tingkat nyeri dengan $p$-value $=0,000(p<0,05)$. Namun tidak terdapat perbedaan signifikan pada tekanan darah sistole dengan $p$-value $=0,725$ dan tekanan darah diastole dengan $p$-value $=0,428$ ( $p>0,05)$. Saran bagi perawat agar melakukan DBE pada pasien post laparatomi karena dapat menurunkan tingkat nyeri.
\end{abstract}

Kata Kunci: post laparatomi, tingkat nyeri, tekanan darah, deep breathing exercise

\section{PENDAHULUAN}

Pembedahan laparatomi merupakan salah satu prosedur pembedahan mayor dengan melakukan penyayatan pada lapisan-lapisan peritoneum untuk mendapatkan bagian organ abdomen yang mengalami masalah (hemoragi, perforasi, kanker, dan obstruksi). Berdasarkan data tabulasi nasional Departemen Kesehatan RI (2011) tindakan bedah salah satunya yaitu laparatomi meningkat $20 \%$ dari 1.320 kasus menjadi 1.567 kasus. Dari data tersebut dapat disimpulkan terdapat peningkatan sebanyak 247.

Masalah yang muncul pasca pembedahan laparatomi adalah kerusakan jaringan yang ditimbulkan akibat insisi pada abdomen. Cedera saraf terjadi ketika saraf terpotong ketika dilakukan insisi, terjerat dengan sutura ketika penutupan, atau tertekan atau teregang dengan retraktor atau instrumen (Mc. Ewen, 2015).

Adanya persepsi nyeri yang dialami individu akan menghasilkan respons terhadap nyeri baik respons fisiologis ataupun respons perilaku dimana masing-masing individu mempunyai karakteristik yang berbeda dalam merespons nyeri tersebut.

Respons fisiologis terhadap nyeri dapat sangat membahayakan individu. Pada saat impuls nyeri naik ke medulla spinalis menuju ke batang otak dan hipotalamus, sistem saraf otonom menjadi terstimulasi sebagai bagian dari respons 
stres. Stimulasi pada cabang saraf simpatis pada sistem saraf otonom menghasilkan respon fisiologis, salah satunya vasokontriksi perifer (pucat, peningkatan tekanan darah) (Sulistyo, 2016).

Respons nyeri pada tubuh akan mempengaruhi sistem kardiovaskuler seperti vasokontriksi yang menimbulkan takikardia, meningkatkan kontraktilitas otot jantung dan resistensi vaskular perifer sehingga terjadilah hipertensi (Mangku \& Senapathi, 2010). Menurut Hambly (2007) menyatakan jangan pernah memberikan obat antihipertensi pada pasien yang kesakitan. Apabila pasien pasca pembedahan mengalami nyeri hebat, maka terjadi vasokontriksi yang menyebabkan tekanan darah meningkat dan juga ketegangan otot yang dapat memicu perdarahan pada luka operasi terutama pada post laparatomi. Bila dibiarkan pasien dapat mengalami syok dan berlanjut pada kematian.

Nyeri pasca pembedahan laparatomi merupakan nyeri akut yang awalnya tiba-tiba. Menurut Yeager, dkk (1987) Beneditti (1984) dalam Smeltzer (2001) mengatakan bahwa apabila nyeri tidak diatasi secara adekuat maka akan mempunyai efek yang membahayakan dan dapat memengaruhi sistem pulmonary, kardiovaskuler, gastrointestinal, endokrin dan imunologik.

Selain nyeri, pada pasien post pembedahan laparatomi juga akan mengalami perubahan tekanan darah. Faktornya dapat dikarenakan nyeri akut akibat insisi luka operasi. Mekanisme perubahan tekanan darah pada pasien dengan nyeri adalah adanya transmisi stimulus nyeri akan naik ke medulla spinalis menuju batang otak dan thalamus. Kemudian akan menstimulasi sistem saraf otonom sebagai bagian dari respons stress. Kemudian menstimulasi cabang simpatis sehingga dapat menyebabkan vasokontriksi yang akan memengaruhi tekanan darah. Sehingga tekanan darah mengalami peningkatan (Potter \& Perry, 2006).
Pada dasarnya terdapat dua cara manajemen nyeri yaitu melalui tindakan farmakologis dan non-farmakologis. Salah satu tindakan nonfarmakologis untuk manajemen nyeri yang dapat dilakukan perawat adalah relaksasi dengan deep breathing exercise atau napas dalam. Relaksasi dapat menurunkan nyeri dengan merilekskan ketegangan otot yang menunjang nyeri dan dapat memberikan kontrol diriketika terjadi rasa tidak nyaman atau nyeri (Potter \& Perry, 2006 dan Smeltzer \& Bare, 2002).

Selain itu, manfaat relaksasi dengan deep breathing exercise atau napas dalam selain untuk menurunkan nyeri, relaksasi ini merupakan suatu teknik yang mudah, murah dan bisa kapan saja dilakukan pasien serta dapat menghilangkan sisasisa obat anastesi inhalasi pada pasien post operasi. Napas dalam merupakan jalan yang cepat untuk mengaktifkan sistem saraf parasimpatis yang sering disebut sebagai respon relaksasi (Pick, 1998 dalam Sunarti dkk., 2013). Sehingga mengatasi nyeri akibat pembedahan salah satunya adalah dengan melakukan relaksasi deep breathing exercise dimana efek relaksasi dapat dilihat dari penurunan skala nyeri dan perubahan tanda-tanda vital (tekanan darah).

Berdasarkan hasil studi pendahuluan yang dilakukan di RS Lavalette Malang pada tanggal 7 Desember 2016 didapatkan data 3 bulan terakhir yaitu bulan Agustus hingga Oktober 2016 pasien dengan tindakan pembedahan laparatomi sebanyak 102. Setelah melakukan observasi pada pasien 1 hari post pembedahan laparatomi di RS Lavalette Malang didapatkan informasi bahwa pasien mengalami nyeri akibat post pembedahan pada daerah abdomen dengan kualitas nyeri: melilit, nyeri dirasakan hilang-timbul dan semakin nyeri bila melakukan perubahan posisi dengan rentang skala nyeri 3-5. Saat dilakukan pengukuran tekanan darah didapatkan hasil 120/70 mmHg.

Hasil wawancara dengan kepala ruang rawat inap bedah di RS Lavalette Kota Malang 
didapatkan informasi tambahan bahwa manajemen nyeri khususnya operasi laparatomi dilakukan secara farmakologi yaitu menggunakan obat-obatan analgesik. Sedangkan tindakan non-farmakologis yang dilakukan adalah KIE distraksi, relaksasi. Nyeri pada pasien post laparatomi muncul pada hari pertama post pembedahan dan rata-rata mengalami nyeri skala sedang hingga berat. Selain itu, pada pasien nyeri seringkali didapatkan perubahan vital sign seperti pada tekanan darah, frekuensi denyut nadi, dan frekuensi pernapasan.

Tujuan penelitian ini adalah mengetahui perbedaan tingkat nyeri dan tekanan darah sebelum dan sesudah deep breathing exercise (DBE) pada pasien post operasi laparatomi.

\section{METODE PENELITIAN}

Desain penelitain ini adalah one group prepost test design. Peneliti ingin mengetahui perbedaan tingkat nyeri dan tekanan darah pada pasien post operasi laparatomi sebelum dan sesudah perlakuan deep breathing exercise (DBE) di Ruang Emerald (Obgyn) RS Lavalette Malang.

Sampel penelitian ini adalah pasien post operasi laparatomi hari ke-1 (24 jam pertama) tiba di ruang perawatan dengan indikasi bedah pada obstetrik dan ginekologi di RS Lavalette Malang pada bulan Agustus-Oktober 2016 sebanyak 20 responden

Metode pengumpulan data adalah menggunakan wawancara dan observasi. Wawancara berisi pertanyaan tentang data karakteristik responden mengenai usia, jenis kelamin, alamat, pendidikan, pengalaman operasi, pengalaman cara mengatasi nyeri, diagnosa medis, riwayat hipertensi dan jenis obat anastesi. Sedangkan observasi berupa lembar pencatatan yang berisi hasil tingkat nyeri dan tekanan darah selama 4 kali observasi pada responden post operasi laparatomi sebelum dan sesudah deep breathing exercise (DBE) di RS Lavalette Malang.
Pengolahan dan analisa data univariat dalam penelitian ini dilakukan dengan cara menghitung jumlah skor pada data khusus. Kemudian dijumlah dan dirata-rata menggunakan rumus mean. Pada data umum yaitu usia, pendidikan dan pengalaman operasi sebelumnya data dapat diolah dengan menggunakan analisis prosentase.

Pada analisis bivariat, data rasio perlu dilakukan uji normalitas terlebih dahulu menggunakan uji Kolmogorov-Smirnov $(K S)$ dengan derajat kepercayaan $95 \% \alpha=0,05$, bermakna $\mathrm{p}<0,05$.

Setelah dilakukan uji KS selanjutnya dilakukan uji statistik. Pada penelitian ini menggunakan analisa komparatif. Sehingga jenis uji statistik yang digunakan apabila hasil uji KS berdistribusi normal adalah menggunakan uji paired $t$-test atau uji beda berpasangan dengan taraf kepercayaan $95 \%$ dan taraf kesalahan 5\% pada derajat kemaknaan $\mathrm{p}<0,05$.

\section{HASIL PENELITIAN}

Hasil penelitan didapatkan hampir sebagian (40\%) responden di RS Lavalette Malang berada pada rentang usia 36-45 tahun yaitu 8 orang responden. Hampir setengahnya (45\%) memiliki tingkat pendidikan sarjana yaitu 9 orang responden dan setengahnya $(50 \%)$ memiliki pengalaman operasi sebelumnya yaitu 10 orang responden.

Berdasarkan tabel 1, rata-rata tingkat nyeri post laparatomi pada pasien sebelum dilakukan tindakan deep breathing exercise (DBE) untuk pertama kalinya (observasi ke-1), sebelum dilakukan DBE untuk kedua kalinya (observasi ke-2), sebelum dilakukan DBE untuk ketiga kalinya (observasi ke-3) dan sebelum dilakukan DBE untuk keempat kalinya (observasi ke-4) cenderung mengalami penurunan

Pada observasi ke-2 (sebelum dilakukan DBE untuk kedua kalinya) tingkat nyeri sedikit mengalami peningkatan dari observasi ke-1 
Tabel 1. Tingkat Nyeri Sebelum dan Sesudah DBE Selama 4 kali Observasi

\begin{tabular}{lcccc}
\hline & Obs. 1 & Obs. 2 & Obs. 3 & Obs. 4 \\
\hline Sebelum DBE & 3,6 & 3,8 & 3,05 & 2,45 \\
Sesudah DBE & 2,95 & 2,9 & 2,4 & 1,65 \\
\hline
\end{tabular}

Tabel 2. Tekanan Sistole Sebelum dan Sesudah DBE Selama 4 kali Observasi

\begin{tabular}{lcccc}
\hline & Obs. 1 & Obs. 2 & Obs. 3 & Obs. 4 \\
\hline Sebelum DBE & 106,5 & 109,5 & 106,5 & 110 \\
Sesudah DBE & 100,75 & 103,5 & 102 & 105,5 \\
\hline
\end{tabular}

Tabel 3. Tekanan Diastole Sebelum dan Sesudah DBE Selama 4 kali Observasi

\begin{tabular}{lcccc}
\hline & Obs. 1 & Obs. 2 & Obs. 3 & Obs. 4 \\
\hline Sebelum DBE & 72 & 73,25 & 70,5 & 71,25 \\
Sesudah DBE & 67,25 & 70,25 & 69 & 70 \\
\hline
\end{tabular}

dengan kenaikan sebesar 0,2. Namun selanjutnya tingkat nyeri mengalami penurunan.

Sedangkan rata-rata tingkat nyeri sesudah dilakukan DBE dari observasi 1-4 cenderung mengalami penurunan. Rata-rata tingkat nyeri sebelum dan sesudah dilakukan DBE pada observasi 1-4 tergolong nyeri ringan.

Berdasarkan Tabel 2, rata-rata tekanan sistole pada pasien post laparatomi sebelum dilakukan tindakan deep breathing exercise (DBE) untuk pertama kalinya (observasi ke-1), sebelum dilakukan DBE untuk kedua kalinya (observasi ke-2), sebelum dilakukan DBE untuk ketiga kalinya (observasi ke-3) dan sebelum dilakukan DBE untuk keempat kalinya (observasi ke-4) cenderung mengalami fluktuasi ke arah peningkatan dimana terjadi peningkatan pada observasi ke- 2 sebesar $3 \mathrm{mmHg}$ dan pada observasi ke-4 sebesar 3,5 mmHg.

Sedangkan rata-rata tekanan sistole sesudah dilakukan DBE dari observasi ke 1-4 cenderung mengalami fluktuasi ke arah peningkatan pula dimana terjadi peningkatan pada observasi ke-
2 sebesar 2,75 mmHg dan pada observasi ke-4 sebesar 3,5 mmHg.

Rata-rata tekanan sistole post laparatomi pada pasien sebelum dan sesudah dilakukan tindakan deep breathing exercise (DBE) secara keseluruhan tergolong tekanan darah normal.

Berdasarkan Tabel 3, rata-rata tekanan diastole pada pasien post laparatomi sebelum dilakukan tindakan deep breathing exercise (DBE) untuk pertama kalinya (observasi ke-1), sebelum dilakukan DBE untuk kedua kalinya (observasi ke-2), sebelum dilakukan DBE untuk ketiga kalinya (observasi ke-3) dan sebelum dilakukan DBE untuk keempat kalinya (observasi ke-4) cenderung mengalami fluktuasi ke arah peningkatan dimana terjadi peningkatan pada observasi ke-2 sebesar 1,25 mmHg dan pada observasi ke-4 sebesar $0,75 \mathrm{mmHg}$.

Sedangkan rata-rata tekanan diastole sesudah dilakukan DBE dari observasi ke 1-4 cenderung mengalami fluktuasi ke arah peningkatan pula dimana terjadi peningkatan pada observasi ke-2 sebesar $3 \mathrm{mmHg}$ dan pada observasi ke-4 sebesar $1 \mathrm{mmHg}$.

Rata-rata tekanan diastole post laparatomi pada pasien sebelum dan sesudah dilakukan tindakan deep breathing exercise (DBE) secara keseluruhan tergolong tekanan darah normal.

Hasil uji normalitas data dengan menggunakan uji Kolmogorov-Smirnov $(K S)$ didapatkan nilai $\mathrm{p}>0,05$ sehingga data terdistribusi normal dan dilanjutkan dengan menggunakan uji paired $t$-test. Hasil uji paired t-test menunjukkan bahwa terdapat perbedaan signifikan sebelum dan sesudah deep breathing exercise (DBE) dari tingkat nyeri dengan $p$ value $=0,000(\mathrm{p}<0,05)$. Namun tidak terdapat perbedaan signifikan pada tekanan darah sistole dengan $p$-value $=0,725$ dan tekanan darah diastole dengan $p$-value $=0,428(\mathrm{p}>0,05)$ pada pasien post operasi laparatomi di RS Lavalette Malang. 


\section{PEMBAHASAN}

Hasil penelitian menunjukkan bahwa ratarata tingkat nyeri post operasi laparatomi pada pasien sebelum dilakukan tindakan deep breathing exercise (DBE) yaitu skala 3,6 dengan kategori nyeri ringan. Faktor-faktor yang memengaruhi skala nyeri tersebut adalah (1) waktu pertama pengambilan data skala nyeri dikarenakan waktu pertama untuk mengobservasi tingkat nyeri sebelum dilakukan DBE adalah pada hari pertama post operasi laparatomi ( $\geq 24$ jam post laparatomi). Hal ini sesuai dengan teori Ekstein (2006) dalam jurnal penelitian Pinandita,I., et al (2012) yang menyatakan bahwa intensitas nyeri pada pembedahan laparaskopi dan laparatomi pada 0-4 jam post operasi masuk dalamkategori hebat dan setelah 24 jam nyeri berkurang. Mulyono (2008) dalam Pinandita, I., et al (2012) menyatakan pula bahwa pemulihan waktu post operasi membutuhkan waktu rata-rata 72,45 menit, sehingga pasien akan merasakan nyeri yang hebat rata-rata pada dua jam pertama setelah operasi karena pengaruh obat anastesi sudah hilang.

Pemberian obat analgesik jenis Ketorolac tromethamine secara kontinu dengan jadwal pemberian $3 \times 30 \mathrm{mg}$ atau setiap 8 jam sekali melalui IV (intravena). Menurut analisis peneliti, pemberian obat analgesik dapat menekan rasa nyeri sehinggga memengaruhi tingkat nyeri responden. Hal ini sesuai dengan Sukandar dkk (2008) dalam Sodikin (2012) yang menyatakan bahwa pemberian obat analgesik (ketorolak 30 $\mathrm{mg} / \mathrm{iv}$ ) sudah menjadi pilihan di rumah sakit untuk mengurangi nyeri paskabedah.

Pada penelitian ini, sebagian besar responden mengalami insisi transversal dan pfannenstiel. Hal tersebut sesuai dengan teori bahwa pada insisi abdomen arah transversal akan terjadi kerusakan syaraf intercostalis minimal bila dibandingkan dengan jenis insisi lainnya yaitu midline.

Seluruh responden penelitian di Ruang Em- erald telah melakukan ambulasi dini berupa miring kanan-kiri. Menurut analisis peneliti, ambulasi dini yang dilakukan oleh responden dapat meningkatkan sirkulasi darah yang akan mempercepat proses penyembuhan luka dan penurunan tingkat nyeri sehingga respons nyeri pun minimal. Hal ini didukung oleh penelitian Rustianawati (2013) yang menyatakan bahwa terdapat perbedaan rata-rata intensitas nyeri pada hari ke 1,2, dan 3 pada responden yang melakukan ambulasi dini. Ambulasi dini dapat meningkatkan sirkulasi darah yang akan memicu penurunan nyeri.

Temuan fakta penelitian juga menunjukkan bahwa tingkat nyeri pada observasi ke-2 mengalami peningkatan yaitu 3,8 bila dibandingkan dengan observasi ke-1 yaitu 3,6 dengan peningkatan sebesar 0,2 . Hasil penelitian juga menunjukkan pada observasi ke- 2 dari 20 responden penelitian, 11 diantaranya mengalami nyeri sedang ( 9 responden) dan nyeri berat terkontrol (2 responden).

Menurut analisis peneliti, hal tersebut dapat dipengaruhi oleh beberapa faktor seperti pengalaman operasi sebelumnya dan faktor usia. Pada penelitian ini, 11 dari 20 responden yang mengalami nyeri sedang-berat pada observasi ke2 menunjukkan 7 diantaranya belum pernah mengalami operasi sebelumnya. Responden yang belum pernah mengalami operasi sebelumnya belum mampu untuk mengatasi dan mentoleransi nyeri yang dialami dibandingkan dengan pasien yang pernah menjalani operasi sebelumnya. Hal tersebut didukung oleh teori Potter \& Perry (2006) yang menyatakan bahwa setiap individu belajar dari pengalaman nyeri. Apabila individu mengalami nyeri yang sama berulang-ulang dan nyeri tersebut berhasil dihilangkan maka akan lebih mudah bagi individu tersebut untuk menginterpretasikan sensasi nyeri.

Pada penelitian ini, 11 dari 20 responden yang mengalami nyeri sedang-berat pada observasi ke-2 menunjukkan 2 diantaranya yang 
mengalami nyeri berat terkontrol berada pada usia 17-35 tahun, 7 responden yang mengalami nyeri sedang berada pada rentang usia 17-45 tahun. Sedangkan responden dengan rentang usia 46-55 tahun mengalami nyeri ringan. Menurut analisis peneliti, usia merupakan salah satu faktor yang bisa memengaruhi persepsi nyeri. Pada usia dewasa lebih mudah untuk mengekspresikan rasa nyeri yang dirasakan dan dapat mendeskripsikan dengan lebih baik dibandingkan dengan usia anak-anak ataupun usia lansia. Hal ini sesuai dengan Smeltzer \& Bare (2001) yang mengatakan bahwa pengkajian nyeri pada lansia mungkin sulit karena perubahan fisiologis dan psikologis serta cara berespons terhadap nyeri berbeda dengan usia yang lebih muda. Persepsi nyeri pada lansia mungkin berkurang sebagai akibat dari perubahan patologis.

Temuan fakta penelitian menunjukkan pula bahwa tingkat nyeri post operasi sebelum dilakukan DBE cenderung mengalami penurunan dari observasi ke-1 hingga observasi ke-4. Menurut analisis peneliti, hal tersebut dipengaruhi oleh faktor-faktor seperti (1) pemberian obatobatan analgesik secara kontinu, (2) nyeri yang tergolong nyeri akut dan (3) adanya proses penyembuhan luka.

Faktor pertama adalah pemberian obatobatan analgesik secara kontinu sehingga menekan rasa nyeri karena mekanisme kerjanya menghambat sintesis prostaglandin dimana prostaglandin merupakan mediator yang menyebabkan persepsi nyeri. Sehingga apabila mediator penyebab nyeri dihambat maka responden dapat lebih tolerir dengan rasa nyeri.

Faktor kedua adalah nyeri yang tergolong nyeri akut. Nyeri akut terjadi karena berkaitan dengan cedera spesifik yaitu luka yang timbul akibat insisi abdomen dimana nyeri tersebut dirasakan setelah selesai pembedahan dan awitannya tiba-tiba. Hal ini sesuai dengan Brunner \& Suddarth (2002) yang menyatakan bahwa nyeri akut biasanya menurun sejalan dengan terjadinya penyembuhan.

Faktor ketiga adalah proses penyembuhan luka. Fase penyembuhan luka turut memengaruhi berkurangnya tingkat nyeri. Nyeri yang ditimbulkan pada observasi ke-4 tidak akan separah pada awal awitan cidera (observasi ke1). Menurut Brunner \& Suddarth (2002) mengatakan bahwa seiring berjalannya fase inflamasi pada proses penyembuhan luka maka luka/cidera semakin tertangani karena secara fisiologis tubuh melakukan kompensasi berupa kontrol perdarahan dan pembentukan sel epitel baru pada lokasi bekas insisi.

Berdasarkan hasil penelitian menunjukkan bahwa rata-rata tingkat nyeri post operasi laparatomi pada pasien sesudah dilakukan tindakan deep breathing exercise (DBE) yaitu skala 1,65 dengan kategori nyeri ringan dengan selisih penurunan sebesar 1,95. Menurut analisis peneliti, hal tersebut salah satunya dipengaruhi oleh tindakan DBE yang dilakukan selama 2 kali dalam sehari selama 10 menit dan diobservasi selama 2 hari berturut-turut karena DBE dapat menurunkan tingkat nyeri dengan mekanisme merangsang aktifitas modulasirefleks sistem saraf simpatis dan frekuensi atau kecepatan pernafasan yang dapat memengaruhi tahanan perifer. Hal ini sesuai dengan teori Kozier, B., et al (2011) bahwa deep breathing exercise merupakan salah satu teknik dalam melakukan relaksasi. Mc. Ewen (2015) juga menyatakan bahwa relaksasi otot skeletal dipercaya dapat menurunkan nyeri dengan merilekskan ketegangan otot yang menunjang nyeri. Relaksasi sangat efektif untuk menurunkan tingkat nyeri ketika dikombinasikan dengan slow, deep, easy breathing dari abdomen atau diafragma.

Hasil penelitian mengenai penurunan tingkat nyeri setelah dilakukan DBE pada responden ini sesuai dengan teori Smeltzer \& Bare (2002) bahwa DBE akan memberikan respon relaksasi karena saraf parasimpatis akan teraktifkan dan menurunkan kadar hormon kortisol dan adrenalin 
dalam tubuh yang memengaruhi tingkat stress seseorang sehingga dapat meningkatkan konsentrasi dan membuat klien merasa tenang untuk mengatur ritme pernapasan menjadi teratur. Pada saat melakukan napas dalam maka akan merangsang tubuh melepaskan menghambat transmisi nyeri: serotonin, opioid endogen yaitu endorphin dan enfekalin yang akan terproduksi dan menghambat mediator nyeri yang dapat menimbulkan nyeri seperti bradikinin, prostaglandin. Sehingga stimulus nyeri yang menuju otak tidak menstimulasi saraf otonom untuk menghasilkan respons stress. Namun akan mengaktifkan sistem saraf parasimpatis sebagai respons relaksasi.

Berdasarkan analisis didapatkan bahwa terdapat perbedaan yang segnifikan dengan $p$ value $=0,000$. Sehingga terbukti bahwa DBE merupakan salah satu teknik yang dapat menurunkan nyeri pada responden post operasi laparatomi di RS Lavalette Malang.

Berdasarkan hasil penelitian menunjukkan bahwa rata-rata tekanan sistole dan diastole post operasi laparatomi pada pasien sebelum dilakukan tindakan deep breathing exercise (DBE) yaitu 106,50 mmHg dan $72 \mathrm{mHg}$ dengan kategori tekanan darah normal. Faktor yang memengaruhi tekanan sistole responden masih dalam rentang normal yaitu (1) penggunaan cairan replacement/preload untuk mengantisipasi hipotensi akibat pemberian obat anastesi SAB (80\% responden mendapatkan pembiusan $\mathrm{SAB}),(2)$ dan nyeri yang tergolong nyeri ringan serta (3) adanya pemberian analgesik secara kontinu yang menyebabkan tingkat nyeri mengalami penurunan (nyeri ringan) sehingga respons fisiologis berupa tekanan sistole berada dalam ambang normal (4) responden tidak memiliki riwayat penyakit hipertensi.

Faktor pertama adalah penggunaan cairan replacement/preload. berupa cairan Ringer Laktat ataupun $\mathrm{NaCl} 0,9 \%$. Penggunaan cairan infus dapat membantu menstabilkan tekanan darah agar dalam batas normal karena pada responden yang mendapatkan pembiusan $\mathrm{SAB}$ akan terjadi penurunan curah jantung. Hal ini sesuai dengan teori Sari (2012) yang menyatakan bahwa responden yang diberikan cairan preload dapat memberikan volume intravaskuler tambahan untuk mempertahankan venous return dan curah jantung, sehingga dapat mempertahankan tekanan darah setelah anestesi spinal dilakukan.

Faktor kedua adalah nyeri yang tergolong nyeri ringan. Pada penelitian ini, pengukuran tekanan sistole dilakukan 24 jam setelah pembedahahan dengan rata-rata tingkat nyeri pada responden adalah 3,6 (nyeri ringan). Penurunan tingkat nyeri tersebut dapat memengaruhi pula respons fisiologis responden (tekanan sistole). Hal ini dikarenakan salah satu respons fisiologis dari nyeri adalah adanya kenaikan tekanan darah. Namun, dikarenakan nyeri tergolong nyeri ringan, maka respon fisiologis yang muncul juga dalam batas normal.

Faktor ketiga adalah pemberian analgesik secara kontinu yang menyebabkan tingkat nyeri mengalami penurunan (nyeriringan) sehingga hal tersebut akan memengaruhi tekanan darah pula. Obat analgesik akan mengurangi transmisi dan resepsi stimulus nyeri yang akan memengaruhi persepsi nyeri pada pasien sehingga apabila nyeri sudah dalam tingkatan yang dapat ditolerir maka perubahan respons fisiologis berupa vasokontriksi perifer/peningkatan tekanan darah cenderung dalam batas normal atau terjadi periode adaptasi fisiologi. Hal tersebut didukung oleh Kozier (2011) yang menyatakan bahwa pasien dengan nyeri berat, periode adapatasi fisiologi dan perilaku dapat terjadi.

Berdasarkan hasil penelitian menunjukkan bahwa tekanan sistole dan diastole selama 4 kali observasi cenderung mengalami fluktuasi ke arah peningkatan. Faktor yang memengaruhi fluktuasi tersebut adalah (1) efek dari obat anastesi SAB yang mulai berkurang dan (2) mobilisasi dini. 
Faktor pertama adalah efek dari obat anastesi $\mathrm{SAB}$ yang mulai berkurang. Efek dari obat anastesi regional (SAB) mulai berkurang pada hari kedua post operasi dibandingkan hari pertama post operasi laparatomi yang mengakibatkan tekanan darah cenderung lebih rendah sehingga mengakibatkan rata-rata tekanan sistole dan diastole pada hari ke-2 post operasi cenderung kembali pada batas normal. Hal ini juga sesuai dengan penelitian Hardiyanto (2006) yang menunjukkan bahwa tekanan darah, frekuensi denyut jantung sebelum, selama, dan setelah anestesi memiliki perbedaan.

Faktor kedua adalah mobilisasi dini. Pada penelitian ini, seluruh responden telah melakukan mobilisasi dini pada hari pertama dan kedua post operasi laparatomi. Mobilisasi dapat memengaruhi tekanan darah karena dapat meningkatkan denyut jantung, curah jantung dan memperlancar sirkulasi darah. Dengan meningkatnya aliran darah secara normal maka akan meningkatkan tekanan darah ke dalam batas normal.

Hal ini sesuai dengan teori Potter \& Perry (2006) yang menyatakan bahwa dengan melakukan latihan atau mobilisasi yang adekuat dapat meningkatkan denyut jantung (heart rate), menguatkan kontraksi otot jantung, dan menyuplai darah ke jantung dan otot. Jumlah darah yang dipompa oleh jantung (cardiac output) meningkat karena aliran balik (venus return) dari aliran darah. Meningkatnya aliran balik dari aliran darah dapat meningkatkan preload ventrikel. Jumlah darah yang dipompa oleh jantung (cardiac output) normal adalah 5 liter/ menit, dengan mobilisasi dapat meningkatkan cardiac output sampai 30 liter/menit.

Berdasarkan hasil penelitian menunjukkan bahwa rata-rata tekanan sistole post operasi laparatomi pada pasien sesudah dilakukan tindakan deep breathing exercise (DBE) yang keempat kalinya (observasi ke-4) yaitu 105,50 $\mathrm{mmHg}$ dengan kategori tekanan darah normal dengan selisih penurunan sebesar 1,00 mmHg. Pada tekanan diastole terdapat penurunan sebesar $2 \mathrm{mmHg}$ menjadi $70 \mathrm{mmHg}$.

Menurut analisis peneliti, hal tersebut salah satunya dipengaruhi oleh tindakan DBE yang dilakukan selama 2 kali dalam sehari selama 10 menit dan diobservasi selama 2 hari berturut-turut karena DBE dapat mengaktifkan kerja parasimpatis sehingga terjadi vasodilatasi pada pembuluh darah yang mengakibatkan turunnya ketegangan dan menimbulkan efek relaksasi. Hal ini didukung oleh teori Smeltzer \& Bare (2002) yaitu DBE dapat memberikan respons relaksasi yang dapat merelaksasikan otot-otot yang mengalami spasme akibat peningkatan prostaglandin sehingga terjadi vasodilatasi pembuluh darah dan akan meningkatkan aliran darah ke daerah yang mengalami spasme/iskemik.

Menurut analisis penelitihal ini terjadi karena tindakan keperawatan non-farmakologis deep breathing exercise (DBE) menyebabkan kondisi responden lebih tenang setelah DBE, sehingga terjadi penurunan ketegangan dan tingkat stress responden. Temuan fakta ini juga semakin membuktikan teori yang ada bahwa terjadinya vasodilatasi pembuluh darah mengakibatkan perubahan tekanan darah. Hal ini diakibatkan karena DBE memiliki kerja yang dapat mengaktifkan saraf parasimpatis yang mempunyai kerja berlawanan dengan sistem saraf simpatis. Sehingga, napas dalam merupakan jalan yang cepat untuk mengaktifkan sistem saraf parasimpatis yang sering disebut sebagai respon relaksasi (Pick, 1998 dalam Sunarti, Sepdianto, \& Tyas, 2013).

Proses DBE dalam memengaruhi tekanan darah menurut Robinson (2014) dalam Richard, S.D., et al. (2015) yaitu DBE dapat mengurangi kecepatan pernapasan (dari 15-20 menjadi 6-10 pernapasan per menit) sehingga dapat meningkatkan volume tidal yang dimaksudkan untuk memelihara ventilasi setiap menit. Saat terjadi peningkatan regangan 
kardiopulmonari terjadi respons stimulasi, dalam keadaan ini dapat menurunan aktivitas simpatis, terjadi perubahan regangan otot, sehingga menyebabkan vasodilatasi.

Proses menurunnya tekanan darah berdasarkan Izzo (2008) dalam penelitian Richard, S.D., et al. (2015) yaitu relaksasi napas dalam dapat mengendorkan atau melemaskan otot-otot tubuh yang tegang sehingga dapat menurunkan denyut nadi, tekanan darah, frekuensi pernapasan dan keringat. Mekanisme relaksasi napas dalam berupa suatu keadaan inspirasi dan ekspirasi pernapasan dengan frekuensi pernapasan menjadi 6-10 kali permenit sehingga terjadi peningkatan regangan kardiopulmonari. Frekuensi atau kecepatan pernapasan pada terapi relaksasi napas dalam (deep breathing) dapat merangsang aktifitas modulasi refleks sistem saraf simpatis dan tahanan perifer. Sehingga, dapat disimpulkan bahwa DBE dapat menghasilkan respons relaksasi yang dapat memengaruhi tekanan darah.

Berdasarkan hasil uji statistik tidak terdapat perbedaan yang signifikan pada tekanan darah sebelum dan sesudah dilakukan DBE dengan $p$ value $=0,725$ pada tekanan sistole dan $p$ value $=0,428(\mathrm{p}>0,05)$ pada tekanan darah diastole. Hal ini dikarenakan perbandingan tekanan darah pada observasi ke-1 sebelum dilakukan DBE dan sesudah dilakukan DBE hingga observasi ke-4 tidak jauh berbeda yaitu sebesar $1,00 \mathrm{mmHg}$ dan sebesar $2 \mathrm{mmHg}$. Hal tersebut dipengaruhi oleh tingkat nyeri pada observasi ke1 yang tergolong ringan yaitu 3,6 sehingga menyebabkan respons fisiologis dari nyeri yaitu vasokontriksi perifer atau kenaikan tekanan darah tidak terjadi dan juga dipengaruhi oleh adapatasi fisiologis dari tubuh. Sehingga tidak terjadi kenaikan darah yang dapat menyebabkan pasien menjadi hipertensi. Hal tersebut sesuai dengan teori Kozier (2011) yang menyatakan bahwa bahkan dengan nyeri berat, periode adaptasi fisiologi dan perilaku dapat terjadi.
Pada observasi ke-4 sesudah dilakukan DBE selama 4 kali, tekanan darah tidak mengalami penurunan yang dapat menghasilkan perbedaan yang signifikan dikarenakan pada observasi ke-1 sebelum DBE tekanan darah sudah dalam batas normal, Sehingga pada observasi ke-4, tekanan darah tetap mengalami penurunan sebagai respons relaksasi setelah dilakukan DBE sebesar 1,00 mmHg untuk sistole dan $2 \mathrm{mmHg}$ untuk diastole namun tidak mengalami penurunan hingga diluar batas normal (hipotensi).

Walaupun hasil tidak signifikan, namun penurunan sebesar 1,00 mmHg untuk tekanan sistole dan $2 \mathrm{mmHg}$ untuk tekanan diastole telah sesuai dengan teori yang ada bahwa efek relaksasi deep breathing exercise yaitu penurunan nadi, tekanan darah, dan pernapasan (Potter \& Perry, 2006). Pada penelitian ini, penurunan secara deskriptif telah terbukti terjadi, namun secara analisis statistik tidak signifikan. Hal ini dikarenakan tekanan darah responden pada awal sebelum dilakukan DBE sudah dalam batas normal dan tidak akan menurun lagi menjadi hipotensi setelah dilakukan DBE. Sehingga, hasil analisis menunjukkan bahwa DBE tidak dapat menurunkan tekanan darah secara signifikan pada pasien post laparatomi yang mengalami nyeri karena tekanan darah awal sebelum DBE sudah dalam batas normal. Namun, penelitian ini juga membuktikan bahwa DBE akan menghasilkan efek relaksasi dengan penurunan tekanan darah yang masih dalam batas normal secara deskriptif di setiap observasi yaitu mulai dari obervasi ke1 hingga ke-4.

\section{PENUTUP}

Simpulan dari penelitian ini adalah terdapat perbedaan yang signifikan sebelum dan sesudah DBE terhadap tingkat nyeri pada pasien post operasi laparatomi di RS Lavalette Malang. Akan tetapi, tidak terdapat perbedaan yang signifikan 
sebelum dan sesudah DBE terhadap tekanan darah sistole dan diastole.

Hasil penelitian ini dapat menjadi pertimbangan untuk mengajarkan teknik deep breathing exercise pada pasien post operasi laparatomi minimal 2 kali dalam sehari dengan bimbingan selama 10-15 menit. Selanjutnya perawat dapat mengedukasi pasien agar melakukan teknik deep breathing exercise secara mandiri untuk dapat diaplikasikan sewaktu-waktu apabila pasien merasa nyeri. Namun, tidak dianjurkan pada pasien yang tmengalami hipotensi karena ditakukan akan semakin menurunkan tekanan darah.

\section{DAFTAR PUSTAKA}

Depkes. (2011). Riset Kesehatan Dasar, (Online), (http://www.depkes.go.id/, diakses pada 3 Januari 2017).

Hambly, P. R. (2007). Manajemen Perioperatif Penatalaksanaan Pasien Bedah di Bangsal. Jakarta: EGC.

Hardiyanto, I. T. (2006). Pengaruh Anestesi Spinal terhadap Hemodinamik Pada Penderita Dengan Sectio Secarea. Karya Tulis ilmiah. FK : UNDIP

Kozier, B., Erb, G., \& Berman, A. S. (2011). Buku Ajar Fundamental Keperawatan: Konsep, Proses \& Praktik, Ed. 7, Vol. 1. Jakarta: EGC.

Kozier, B., Erb, G., Berman, A., \& Snyder, S. J. (2011). Buku Ajar Fundamental Keperawatan: Konsep, Proses \& Praktik, Ed. 7 , Vol. 2. Jakarta: EGC.

Mangku, G., \& Senapathi, T. G. (2010). Buku Ajar Ilmu Anastesia dan Reanimasi. Jakarta: Indeks.

McEwen, D. (2015). Alexander's Care of the Patient In Surgery, 15th Edition. Missouri: Elsevier Mosby.

Pinandita, I., et al. (2012). Pengaruh Teknik Relaksasi Genggam Jari Terhadap Penuru- nan Intensitas Nyeri Pada Pasien Post Operasi Laparatomi. Jurnal Ilmiah Kesehatan Keperawatan Vol 8(1): 32-43. .

Potter, \& Perry. (2006). BukuAjar Fundamental Keperawatan: Konsep, Proses, dan Praktik, Ed.4, Vol.2. Jakarta: EGC.

Richard, S. D., \& Noritasari, F. N. (2015). Potensi Relaksasi Napas Dalam Menurunkan Pre-Menstruation Syndrome Pada Remaja Putri. Jurnal Penelitian Keperawatan Vol 1(1): 43-52.

Rustianawati, Y. (2013). Efektivitas Ambulasi Dini terhadap Penurunan Intensitas Nyeri pada Pasien Post Operasi Laparatomi di RSUD Kudus. JIKK Vol 4(2): 1-8.

Sari, K. N. (2012). Perbedaan Tekanan Darah Pasca Anastesi Spinal dengan Pemberian Preload dan Tanpa Pemberian Preload 20cc/kgBB Ringer Laktat. Program Pendidikan Sarjana Kedokteran Universitas Diponegoro: Skripsi dipublikasikan.

Smeltzer, \& Bare. 2002. Buku Ajar Keperawatan Medikal Bedah, Edisi 8. Jakarta: EGC.

Smeltzer, Suzanne, 2001. Buku Ajar Keperawatan Medikal Bedah, edisi 8 Volume 1. Jakarta: EGC

Sodikin. 2012. Pengaruh Terapi Bacaan AlQuran Melalui Media Audio Terhadap Respon Nyeri Pasien Post Operasi Hernia Di RS Cilacap. Program Magister Ilmu Keperawatan Fakultas Ilmu Keperawatan Universitas Indonesia: Tesis dipublikasikan.

Sulistyo, A. 2016. Konsep \& Proses Keperawatan Nyeri. Jogjakarta: Ar-Ruzz.

Sunarti, Sepdianto, T. C., \& Tyas, M. D. 2013. Pengaruh Breathing Retraining Terhadap Forced Expiratory Volume dan Saturasi Oksigen Pasien Penyakit Paru Obstruktif Kronis di RSD Mardi Waluyo Kota Blitar. Malang: Poltekkes Kemenkes Malang. 